\title{
DIMINISHED WEIGHT OF RAT FOETUSES AFTER TREATMENT OF PREGNANT RATS WITH HALOPERIDOL
}

\author{
N. EINER-JENSEN AND N. J. SEGHER \\ Institute of Physiology, University of Odense, Denmark
}

(Received 6th April 1970)

\begin{abstract}
Summary. Daily treatment for 3 to 9 days with 3 to $12 \mathrm{mg} / \mathrm{kg}$ haloperidol (4-[4-(p-chlorophenyl) - 4-hydroxypiperidino] - 4' - fluorobutyrophenone) given by stomach tube to pregnant rats delays the growth of the foetuses, if treatment is started on the day of copulation (Day 0) or the day after. The delay is not seen if treatment is started on Days 4 or 7. If 3 to $9 \mathrm{mg} / \mathrm{kg}$ haloperidol is administered on Day 1 to Day 16 , the young are normal in appearance at birth, but with 1 to 6 days' delay. These findings could indicate that implantation is initiated earlier than is generally accepted.
\end{abstract}

The butyrophenone derivative, haloperidol (4-[4-(p-chlorophenyl)-4-hydroxypiperidino]-4'-fluorobutyrophenone), causes retarded implantation if administered to pregnant rats (Tuchmann-Duplessis \& Mercier-Parot, 1967). The present investigation was carried out in order to detect at which stage of pregnancy haloperidol could interfere with the weight increase of the foetuses and, thus, indirectly influence the implantation process.

In our experiments, rats were maintained in cages, each cage containing five mature, female, Sprague-Dawley rats and one mature male. Vaginal smears were taken from the females every morning. On the first day (Day 0) on which spermatozoa were observed in the smear, the females were placed in separate cages and randomly distributed between test groups and parallel control groups. Haloperidol (Janssen Pharmaceutical) was dissolved in distilled water and administered by stomach tube daily for 3 to 9 days in doses of 3 , 6,9 or $12 \mathrm{mg} / \mathrm{kg}$. The exact days of drug administration are given in Table 1 . Control animals were given $0.1 \mathrm{ml}$ distilled water $/ 100 \mathrm{~g}$ body weight. The haloperidol solution was kept at $5^{\circ} \mathrm{C}$ and a fresh solution was prepared every week.

The female rats were killed on Day 20, the foetuses were counted and their body weight estimated to an accuracy of within $10 \mathrm{mg}$. In one series, the animals were given haloperidol from Days 1 to 16 . The animals in this series were not killed, but allowed to proceed to term, and the day of delivery was noted (Table 2).

The body weight of the foetuses recorded on Day 20 was less when haloperidol had been administered from Day 0 or Day 1. The mean body 
weight of such foetuses on Day 20 was $2 \cdot 8 \mathrm{~g}$. If administration was started later, on Day 4 or Day 7, the mean weight was $3.5 \mathrm{~g}$. The mean weight of the foetuses from the control animals was $3 \cdot 7 \mathrm{~g}$ (Table 1 ). A tendency to a doseresponse relationship could be seen in the groups treated on Day 0 or Day 1 so that a higher haloperidol dose was associated with a lower mean body

TABLE 1

NUMBER AND MEAN WEIGHTS OF FOETUSES OF PREGNANT RATS AFTER TUBE-FEEDING WITH HALOPERIDOL

\begin{tabular}{|c|c|c|c|c|}
\hline \multicolumn{2}{|c|}{ Haloperidol } & \multirow{2}{*}{$\begin{array}{l}\text { No. of pregnant } \\
\text { rats with living } \\
\text { foetuses/no. } \\
\text { of the group }\end{array}$} & \multirow{2}{*}{$\begin{array}{l}\text { No. of living } \\
\text { foetuses/mother }\end{array}$} & \multirow[t]{2}{*}{ Mean foetus weight } \\
\hline$m g / k g$ & Day & & & \\
\hline $\begin{array}{r}3 \\
6 \\
3 \\
6 \\
9 \\
12 \\
3 \\
3 \\
6 \\
9\end{array}$ & $\begin{array}{r}0 * \text { to } 3 \\
0 \text { to } 3 \\
1 \text { to } 3 \\
1 \text { to } 3 \\
1 \text { to } 3 \\
1 \text { to } 3 \\
0 \text { to } 8 \\
1 \text { to } 8 \\
1 \text { to } 8 \\
1 \text { to } 8\end{array}$ & $\begin{array}{c}4 / 4 \\
4 / 5 \\
1 / 5 \\
4 / 10 \\
3 / 5 \\
1 / 6 \\
2 / 5 \\
11 / 16 \\
0 / 5 \\
1 / 3 \\
31 / 64 t\end{array}$ & $\begin{array}{c}11 \\
10 \\
9 \\
8 \\
11 \\
4 \\
8 \\
9 \\
0 \\
11 \\
9 \cdot 4 \ddagger\end{array}$ & $\begin{array}{l}3 \cdot 26 \\
2 \cdot 79 \\
3 \cdot 44 \\
3 \cdot 00 \\
2 \cdot 56 \\
3 \cdot 02 \\
1 \cdot 42 \\
2 \cdot 83 \\
- \\
2 \cdot 49 \\
2 \cdot 81 \ddagger\end{array}$ \\
\hline $\begin{array}{l}3 \\
6 \\
3 \\
3 \\
6\end{array}$ & $\begin{array}{l}4 \text { to } 6 \\
4 \text { to } 6 \\
4 \text { to } 9 \\
7 \text { to } 9 \\
7 \text { to } 9\end{array}$ & $\begin{array}{c}4 / 9 \\
3 / 5 \\
2 / 5 \\
1 / 6 \\
3 / 5 \\
13 / 30 \dagger\end{array}$ & $\begin{array}{l}9 \\
9 \\
11 \\
10 \\
11 \\
10 \cdot 0 \ddagger\end{array}$ & $\begin{array}{l}3 \cdot 32 \\
3 \cdot 72 \\
3 \cdot 74 \\
3 \cdot 09 \\
3 \cdot 57 \\
3 \cdot 53 \ddagger\end{array}$ \\
\hline \multicolumn{2}{|c|}{ Control } & $27 / 47$ & $9 \cdot 6$ & $3 \cdot 68$ \\
\hline
\end{tabular}

* Day 0 was the day on which spermatozoa were first observed in a vaginal smear. Animals were killed on Day 20. Three foetuses from control animals and three from animals treated with haloperidol were dead at Day 20.

$\dagger$ Total. $\ddagger$ Mean.

TABLE 2

DAY OF BIRTH AND NUMBER OF LIVING YOUNG OF PREGNANT RATS AFTER PROLONGED TUBE-FEEDING WITH HALOPERIDOL

\begin{tabular}{c|c|c|c|c}
\hline \multicolumn{2}{c|}{ Haloperidol } & $\begin{array}{c}\text { Total no. of } \\
\text { rats bearing } \\
\text { young }\end{array}$ & $\begin{array}{c}\text { Total no. of } \\
\text { young born }\end{array}$ & Day of birth \\
\hline$m g / k g$ & Day & 3 & 24 & $22,23,23$ \\
\hline 3 & 1 to 16 & 3 & 19 & $27,24,26$ \\
6 & 1 to 16 & 2 & 17 & 27,27 \\
9 & 1 to 16 & $8 \dagger$ & $60 \dagger$ & $25 \ddagger$ \\
\hline & & 10 & $101^{*}$ & $8 \times 21$ \\
Control & & & $1 \times 18$ \\
& & & \\
\hline
\end{tabular}

* Seven dead young are included in this number.

† Total. $\ddagger$ Mean. 
weight for the foetuses. Prolongation of the treatment until Day 8 instead of Day 3, or start of haloperidol administration on Day 0 instead of Day 1, also seemed to increase the effect on the foetuses. The body weight of the control foetuses showed an almost typical Gaussian distribution curve. Administration of haloperidol early in pregnancy changed the distribution radically. Only a few of the 290 foetuses were grouped around the mean weight $(2.8 \mathrm{~g})$. Most of the foetuses were concentrated in two nearly separate groups on either side of the mean. Foetuses from animals given haloperidol from Day 4 or Day 7 showed a distribution of weights around the mean weight of the control animals. Three control animals and three haloperidol-treated animals delivered young before the day planned for the termination of the experiment (Day 20). Of the fourteen animals dosed with haloperidol from Days 1 to 16 , eight animals delivered living young. The maximum delay was 6 days, the mean, 4 days (Table 2).

The first part of the experiment showed that foetal development could be delayed if haloperidol was administered for a few days between conception and implantation, but if administered during, or after, implantation, the effect was weak or doubtful.

Bindon (1969) has shown that trifluoperazine (also a major tranquillizer) could diminish the weight of the uterus and foetuses in mice as determined on Day 9 after a single administration at 16.00 hours 2 days after observing spermatozoa in the vaginal smear, but not if administered at 24.00 hours on the same day, or at 08.00 or 16.00 hours 3 days after the start of pregnancy. Earlier administration was not tried. Bindon's results with mice and our experiments with rats indicate that haloperidol can delay the development of the foetuses in the same way in both species.

Like reserpine (Mayer, Meunier \& Thévenot-Duluc, 1960), haloperidol changes the endocrinological balance. After daily treatment with $10 \mathrm{mg} / \mathrm{kg}$ haloperidol to female rats, most of the animals showed an increased number of atretic follicles and hypertrophy of the interstitial gland. The mammary glands showed a marked hypertrophy and were, from a histological point of view, very similar to the actively lactating gland (Tuchmann-Duplessis \& Mercier-Parot, 1966). The histological picture was the same as that obtained in the presence of a hypophysial autograft in the kidney or after reserpine administration (Mayer 1965). This indicates that tranquillizers are able to inhibit the secretion of FSH and LH and simultaneously to stimulate the secretion of LtH, probably through inhibition of the secretion of the LtH-inhibiting factor from the hypothalamus. This will lead to a relative reduction in the influence of oestrogens upon the uterus compared to progesterone, which explains why the state seems similar to delayed implantation caused by supplying progesterone to ovariectomized animals in early pregnancy.

Shelesnyak (1960) assumes the existence of an oestrogen 'surge' reaching the uterus in the afternoon of the day before implantation in the rat. Our results show that the development of the foetuses can be influenced from the earliest days of the pregnancy, suggesting that implantation is initiated earlier than is generally accepted. 


\section{REFERENCES}

Bindon, B. M. (1969) The role of the pituitary gland in implantation in the mouse: Delay of implantation by hypophysectomy and neurodepressive drugs. $\mathcal{F}$. Endocr. 43, 225.

MAYER, G. (1965) Tranquillizers and nidation. In: Agents affecting Fertility, p. 290. Eds. G. R. Austin and J. S. Perry. Churchill, London.

Mayer, G., Meunier, J.-M. \& Thevenot-Duluc, A. J. (1960) Prolongation de la grossesse par retards de nidation obtenus chez la ratte par administration de reserpine. Annls Endocr. 21, 1.

ShelesNyak, M. C. (1960) Nidation of the fertilized ovum. Endeavour, 19, 81.

Tuchmann-Duplessis, H. \& Mercier-Parot, L. (1966) Action d'un neuroleptique, le R 1625 (Haloperidol) sur l'activité génitale de la ratte. C. r. hebd. Séanc. Acad. Sci., Paris, 263, Série D, 1493.

Tuchmann-Duplessis, H. \& Mercier-Parot, L. (1967) Nidation retardée sous l'influence d'un neuroleptique le R 1625 (haloperidol). C. r. hebd. Séanc. Acad. Sci., Paris, 264, Série D, 114. 